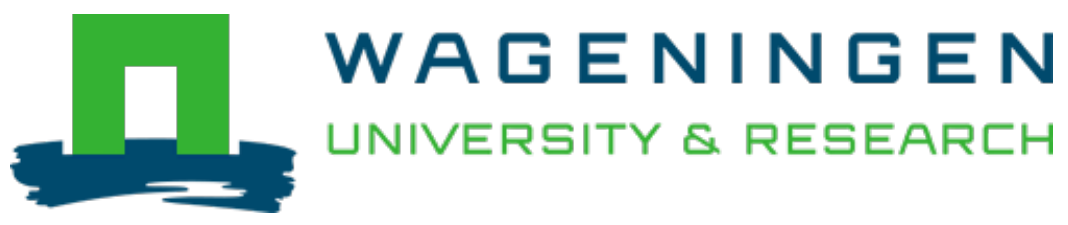

\title{
Syndromes of production in intercropping impact yield gains
}

Nature Plants

\author{
Li, Chunjie; Hoffland, Ellis; Kuyper, Thomas W.; Yu, Yang; Zhang, Chaochun et al \\ https://doi.org/10.1038/s41477-020-0680-9
}

This publication is made publicly available in the institutional repository of Wageningen University and Research, under the terms of article $25 \mathrm{fa}$ of the Dutch Copyright Act, also known as the Amendment Taverne. This has been done with explicit consent by the author.

Article $25 \mathrm{fa}$ states that the author of a short scientific work funded either wholly or partially by Dutch public funds is entitled to make that work publicly available for no consideration following a reasonable period of time after the work was first published, provided that clear reference is made to the source of the first publication of the work.

This publication is distributed under The Association of Universities in the Netherlands (VSNU) 'Article $25 \mathrm{fa}$ implementation' project. In this project research outputs of researchers employed by Dutch Universities that comply with the legal requirements of Article $25 \mathrm{fa}$ of the Dutch Copyright Act are distributed online and free of cost or other barriers in institutional repositories. Research outputs are distributed six months after their first online publication in the original published version and with proper attribution to the source of the original publication.

You are permitted to download and use the publication for personal purposes. All rights remain with the author(s) and / or copyright owner(s) of this work. Any use of the publication or parts of it other than authorised under article $25 \mathrm{fa}$ of the Dutch Copyright act is prohibited. Wageningen University \& Research and the author(s) of this publication shall not be held responsible or liable for any damages resulting from your (re)use of this publication.

For questions regarding the public availability of this publication please contact openscience.library@,wur.nl 


\title{
Syndromes of production in intercropping impact yield gains
}

\author{
Chunjie Li $\odot^{1,2,3}$, Ellis Hoffland $\oplus^{2}$, Thomas W. Kuyper $\oplus^{2}$, Yang $\mathrm{Yu}^{3}$, Chaochun Zhang ${ }^{1}$, \\ Haigang Li $\oplus^{1,4}$, Fusuo Zhang $\oplus^{1 凶}$ and Wopke van der Werf $\oplus^{3 凶}$
}

\begin{abstract}
Intercropping, the simultaneous production of multiple crops on the same field, provides opportunities for the sustainable intensification of agriculture if it can provide a greater yield per unit land and fertilizer than sole crops. The worldwide absolute yield gain of intercropping as compared with sole crops has not been analysed. We therefore performed a global meta-analysis to quantify the effect of intercropping on the yield gain, exploring the effects of crop species combinations, temporal and spatial arrangements, and fertilizer input. We found that the absolute yield gains, compared with monocultures, were the greatest for mixtures of maize with short-grain cereals or legumes that had substantial temporal niche differentiation from maize, when grown with high nutrient inputs, and using multirow strips of each species. This approach, commonly practised in China, provided yield gains that were (in an absolute sense) about four times as large as those in another, low-input intercropping strategy, commonly practised outside China. The alternative intercropping strategy consisted of growing mixtures of short-stature crop species, often as full mixtures, with the same growing period and with low to moderate nutrient inputs. Both the low- and high-yield intercropping strategies saved $16-29 \%$ of the land and $19-36 \%$ of the fertilizer compared with monocultures grown under the same management as the intercrop. The two syndromes of production in intercropping uncovered by this meta-analysis show that intercropping offers opportunities for the sustainable intensification of both high- and low-input agriculture.
\end{abstract}

W ith the ongoing increase in the global population and demand for food, improving crop productivity is a pressing challenge ${ }^{1}$. Intensive agriculture provides high yields but comes with serious environmental impacts ${ }^{2-4}$. Intercropping (that is, the mixed cultivation of crop species on the same field ${ }^{5,6}$ ) is a sustainable way to develop productive agriculture ${ }^{6-8}$ : it offers ecological mechanisms for weed suppression', pest and disease control $^{10,11}$, efficient use of light ${ }^{12}$ and water ${ }^{13-15}$, conservation of soil resources $^{16-18}$, and yield increase ${ }^{19-21}$. The most obvious advantage of intercropping is land sparing, which is usually quantified by the land equivalent ratio (LER). The LER is defined as the ratio of the area under sole cropping to the area under intercropping needed to give the same yields ${ }^{22}$. An LER greater than one means that intercropping saves land. Previous meta-analyses have shown that the LER of intercropping averages $1.22 \pm 0.02$ (ref. ${ }^{23}$ ) or $1.30 \pm 0.01$ (ref. ${ }^{8}$ ), depending on the studies selected for meta-analysis. However, the LER is a dimensionless indicator of relative yields in intercropping compared with monocultures. It does not provide information on the absolute yield increase per unit area achieved by intercropping.

The absolute yield gain of species mixtures can be assessed by the net effect (NE) of species mixtures on the yield per unit area ${ }^{24}$. The NE is defined as the difference in yield or biomass between the mixture and the average of the sole crops ${ }^{24}$. The information provided by the NE and the LER is complementary. Both metrics are relevant for assessing the benefit of intercropping. The LER evaluates the comparative land use efficiency of intercropping, while the NE indicates how much more yield is produced per unit area than expected on the basis of sole crop yields and species proportions. The relative yield can be high at low-yield levels, but the NE is not likely to be substantial at low-yield levels. When issues of global food security are at stake, it is important to not focus solely on the land use efficiency (LER) but to also pay attention to the NE (that is, the absolute yield gain). The absolute yield gain of intercropping at a global scale is unknown.

Intercropping is an ancient cropping system, practised all around the world ${ }^{25,26}$ (Supplementary Fig. 1). Various crop combinations have been recognized and utilized in Africa, Asia, Europe and the Americas for centuries and are still prevalent ${ }^{27}$. Crop species may be grown simultaneously or partly so, and in no distinct row arrangement (mixed) or in alternate rows or strips on the same field ${ }^{25}$ (Fig. 1). In strip intercropping, the strips are wide enough to permit independent cultivation but narrow enough to allow beneficial interspecific interactions ${ }^{6}$ (Fig. 1a,b,e-g).

Maize (Zea mays) is a frequently used species in intercropping. This high-yielding $\mathrm{C} 4$ species can be sown in strips of several rows, alternating with several rows of a C3 species (for example, a small grain such as wheat (Triticum aestivum) ${ }^{28}$ or a legume such as soybean $\left(\text { Glycine } \mathrm{max}^{29}\right)^{29}$. Maize has a late and long growing season and is usually harvested after a $\mathrm{C} 3$ species in a system known as relay strip intercropping ${ }^{25,26,30}$ (Fig. 1b).

Maize and other cereals can also be sown in alternate rows or mixed in a more or less random pattern with other small grains or legumes (Fig. 1c,d). Alternate-row and mixed intercropping are popular in organic farming with low input in Europe $e^{1,3,31,32}$. Here, mixtures of a legume and a C3 cereal species are the most popular combination (Fig. $1 \mathrm{~h}-\mathrm{j}$ ). These intercropping systems have low nitrogen $(\mathrm{N})$ fertilizer input but realize an acceptable protein content in the cereal grain due to $\mathrm{N}_{2}$ fixation by the legumes.

${ }^{1}$ College of Resources and Environmental Science, National Academy of Agriculture Green Development, China Agricultural University, Beijing, China. ${ }^{2}$ Soil Biology Group, Wageningen University, Wageningen, The Netherlands. ${ }^{3}$ Centre for Crop Systems Analysis, Wageningen University, Wageningen, The Netherlands. ${ }^{4}$ College of Grassland, Resources and Environment, Inner Mongolia Agricultural University, Hohhot, China. ${ }^{凶}$ e-mail: zhangfs@cau.edu.cn; wopke.vanderwerf@wur.nl 


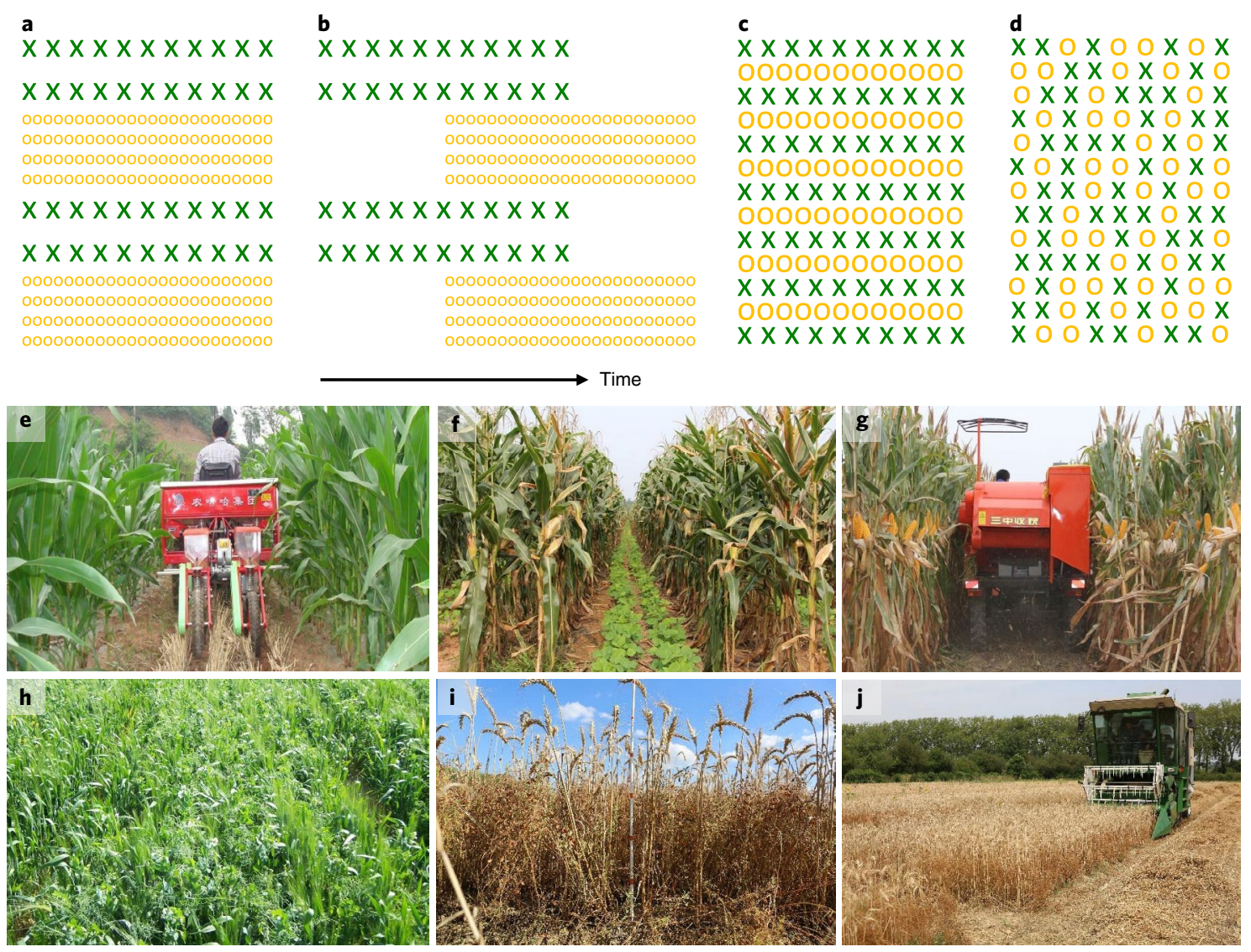

Fig. 1 | Schematic illustrations and examples of alternative intercropping strategies. a, Strip intercropping, with both species grown simultaneously. b, Relay strip intercropping, with one species sown and harvested later than the other. c, Alternate-row intercropping. d, Mixed intercropping. e, A mini tractor sowing soybean and applying fertilizer in maize/soybean relay strip intercropping ${ }^{46}$. $\mathbf{f}$, Relay strip intercropping of maize and soybean ${ }^{46}$. $\mathbf{g}, \mathrm{A}$ soybean harvester working in a soybean strip in Southwest China ${ }^{46} . \mathbf{h}$. Alternate-row intercropping of durum wheat and winter pea in France ${ }^{68}$. $\mathbf{i}$, Mixed lentil/spring wheat intercropping at harvest ${ }^{58}$. j, Mechanical harvest of mixed lentil/spring wheat intercropping in France ${ }^{58}$. Adapted with permission from refs. ${ }^{46,58,68}$.

These systems have the advantages of low input and low emissions $^{33,34}$. However, due to lower inputs, they are also comparatively low yielding. In these systems, the intercropped species are mostly sown in full mixtures that are harvested at the same time ${ }^{21}$ (that is, without temporal niche differentiation (TND)).

We previously found that intercrops with maize in China have greater yield gains than intercrops without maize ${ }^{35}$. The LER was increased at greater TND (ref. ${ }^{23}$ ) and at lower $\mathrm{N}$ input ${ }^{36}$. However, the effects of these management factors on the NE of intercropping on yield have not been studied at a global scale. We therefore investigate here the effects of species combinations, temporal and spatial arrangements, and fertilizer input on the yield gain at a global scale.

We present here a global meta-analysis to quantify the yield gain for grain-producing intercropping systems with different species combinations (with or without maize), temporal and spatial arrangements, and fertilizer inputs. We also evaluated whether intercropping can save land and fertilizer. The land and fertilizer savings were quantified with relative metrics ${ }^{8,23,29}$, while the yield gains were assessed with an absolute yield metric ${ }^{24}$. We show that the greatest absolute yield gains are achieved when the management factors are coordinated in a high-input, high-output syndrome of production $^{37,38}$ in intercropping, with a substantial input of fertilizer, the inclusion of maize in the mixture, cultivation in strips and the use of relay intercropping. Substantially smaller yield gains, but still considerable land and fertilizer savings compared with sole crops under the same management, are obtained in a low-input, low-output intercropping strategy, without maize, and with fully mixed intercrops without TND.

\section{Results}

The overall yield gain (NE) in intercropping was $1.5 \pm 0.1 \mathrm{Mgha}^{-1}$ (mean \pm s.e.m.) in this global dataset. The NE was positive in $87 \%$ of the data records (Fig. 2a). The yield gains differed between intercrops with or without maize and between intercrops in different spatial arrangements. The $\mathrm{NE}$ was $2.1 \pm 0.1 \mathrm{Mgha}^{-1}$ in intercrops with maize, approximately four times as high as in intercrops without maize $\left(0.5 \pm 0.1 \mathrm{Mgha}^{-1}\right)$ (Fig. 2b and Supplementary Fig. 3). When the NE was compared between intercrops with or without maize receiving $\mathrm{N}$ input less than the median value of $75 \mathrm{kgN} \mathrm{ha}^{-1}$ in the dataset, or at least this amount, the overall effect of $\mathrm{N}$ input was non-significant $(P=0.32)$, but there was a significant interaction $(P=0.01)$, indicating contrasting responses to $\mathrm{N}$ input in intercrops with or without maize (Fig. 2b). The NEs were similar in strip and alternate-row intercrops $\left(1.5 \pm 0.1\right.$ and $1.4 \pm 0.1 \mathrm{Mgha}^{-1}$, respectively; Fig. 2c), but the NEs were significantly greater in these two spatial arrangements than in fully mixed intercrops $\left(1.0 \pm 0.2 \mathrm{Mgha}^{-1}\right)$. The spatial arrangement effects were confounded with those of the presence of maize, the fertilizer input and the use of relay intercropping.

We used an index for TND to characterize complementarity in growing periods between the intercropped species. TND quantifies the total period of non-overlap as a proportion of the total growing 


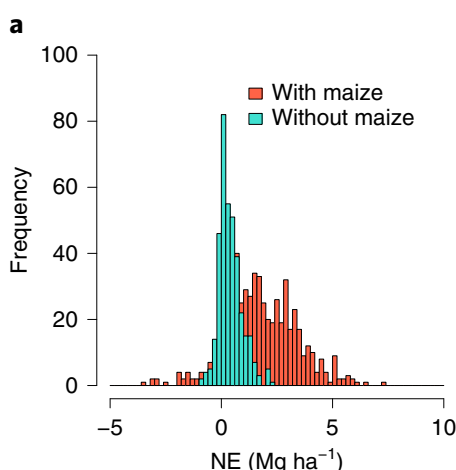

d

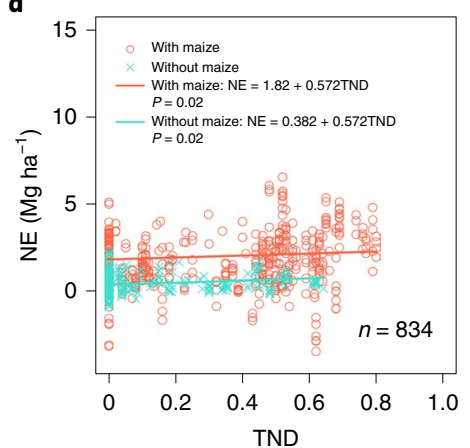

b
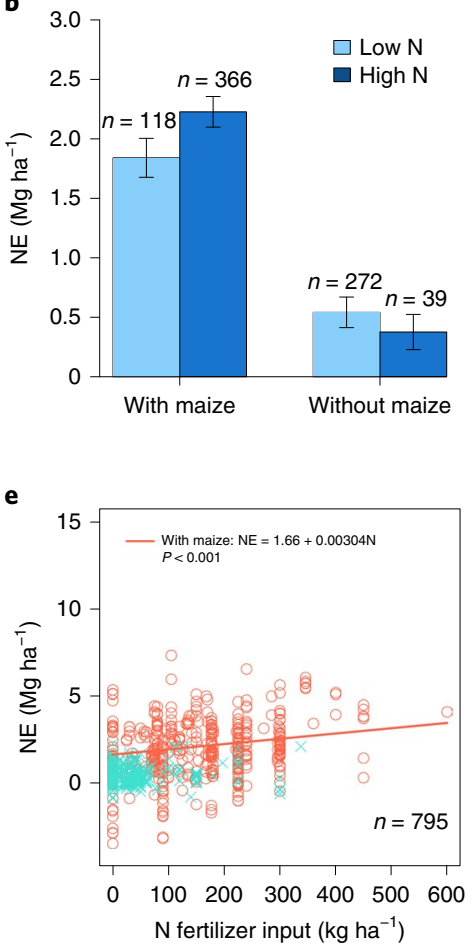

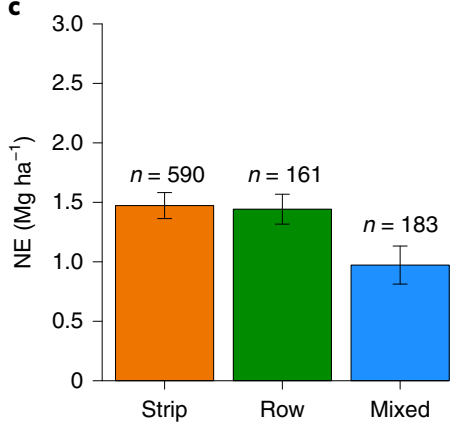

f

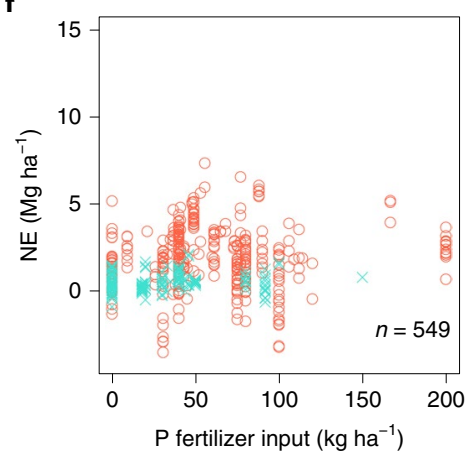

Fig. 2 | NEs of various types of intercropping and the associations with TND and fertilizer inputs. a, Frequency distribution of the NEs of intercrops with and without maize. $\mathbf{b}$, Interaction between the effects of $N$ input (high $N$ input, $\geq 75 \mathrm{~kg} \mathrm{ha}^{-1}$; low $\mathrm{N}$ input, $<75 \mathrm{~kg}^{-1}$ ) and maize presence on yield gain. c, NEs of intercrops with different spatial arrangements. The bars represent the estimated means based on a mixed-effects model. The error bars represent the standard error of the mean; $n$ is the number of data records (this applies to all figures). $\mathbf{d}-\mathbf{f}$, Relationships between NE and TND (d), N fertilizer input (e) and $\mathrm{P}$ fertilizer input (f). Only the regressions with $P<0.05$ are presented.

period of the two species on a scale from 0 (simultaneous growth) to 1 (the first species is harvested before the second is sown) ${ }^{23}$. The $\mathrm{NE}$ increased $0.6 \pm 0.2 \mathrm{Mgha}^{-1}$ per unit of TND $(P=0.02$, Fig. $2 \mathrm{~d})$ in intercrops both with and without maize. The NE of intercrops with maize increased $3.0 \pm 0.5 \mathrm{kgha}^{-1}$ per kilogram of $\mathrm{N}$ fertilizer per hectare, but the NE of intercrops without maize was independent of $\mathrm{N}$ fertilizer input. There was no response of the NE to phosphorus (P) fertilizer input, irrespective of whether maize was included in the intercrop.

The temporal and spatial arrangements, fertilizer input and species selection differed between intercropping systems with and without maize. TND was significantly larger $(P<0.001)$ in intercrops with maize $(0.3 \pm 0.03)$ than in intercrops without maize $(0.1 \pm 0.03$, Fig. $3 a)$ (that is, the relative cogrowth period of the crop species was shorter in intercropping systems with maize than in systems without maize).

Nitrogen fertilizer input was three times as high in intercrops with maize $\left(155 \pm 10 \mathrm{kgha}^{-1}\right)$ as in intercrops without maize $\left(46 \pm 10 \mathrm{~kg} \mathrm{ha}^{-1}\right)(P<0.001$, Fig. $3 \mathrm{~b})$. The $\mathrm{P}$ fertilizer rate was similar in intercrops with and without maize $(P=0.08$, Fig. $3 b)$.

The observed yield of intercrops with maize $\left(8.9 \pm 0.3 \mathrm{Mgha}^{-1}\right)$ was $5.5 \mathrm{Mgha}^{-1}$ higher $(P<0.001)$ than the observed yield of intercrops without maize $\left(3.4 \pm 0.3 \mathrm{Mgha}^{-1}\right.$, Fig. $\left.3 \mathrm{c}\right)$. The expected yield (calculated as the product of the monoculture yield and the land share of component species in intercropping) of intercrops with maize $\left(6.7 \pm 0.2 \mathrm{Mgha}^{-1}\right)$ was $3.7 \mathrm{Mgha}^{-1}$ higher than the expected yield of intercrops without maize $\left(3.0 \pm 0.2 \mathrm{Mgha}^{-1}\right.$, Fig. $\left.3 \mathrm{c}\right)$.

There were marked differences in spatial arrangement and companion species between intercropping systems with and without maize. Most of the intercrops with maize were arranged in strips (461 out of 568 records, Fig. 4a), and far fewer records represented intercrops with maize grown in alternate rows (79 out of 568) or fully mixed with the companion species (28 out of 568). Of the intercrops without maize, 155 of 366 records were mixed intercropping, 82 records were alternate-row intercropping and 129 records were strip intercropping (Fig. 4a). Legumes such as pea (Pisum sati$v u m$ ), faba bean (Vicia faba), soybean and peanut (Arachis hypogaea) were the most common companion species in intercrops with maize (436 records, Fig. 4b) (Supplementary Table 1). There was also a substantial number of observations (120 records) of maize intercropped with small grains, such as wheat or barley (Hordeum vulgare) (Supplementary Fig. 2). Intercrops without maize were dominated by legume-based intercrops ( 352 out of 366 records, Fig. $4 \mathrm{~b}$ ), such as mixtures of legumes with small grains (wheat, barley, oats (Avena sativa) or rice (Oryza sativa), 284 records), another legume species ( 25 records) or another species (43 records), such as oilseed rape (Brassica napus) or sesame (Sesamum indicum). Only 14 records of intercrops without maize included a non-legume species (Supplementary Table 1).

Of a total of 426 records originating from China, 384 records concerned intercropping with maize, whereas a smaller proportion of records originating from studies outside China (184 out of 508 records) concerned intercropping with maize (Fig. 4c). A majority of records (324 out of 508) originating from studies outside China concerned intercropping without maize. These studies originated from Europe (44\%), Asia (32\%) and Africa (17\%) (Supplementary Fig. 4).

The results of a principal component analysis illustrate the existence of two contrasting syndromes of production in intercropping (Fig. 5). On the one hand, there are systems with maize with high yield levels, high $\mathrm{N}$ input and strip intercropping with large values of TND (high loadings on principal component 1, Supplementary 
a

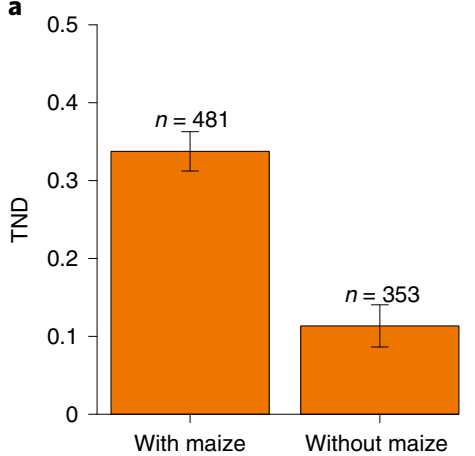

b

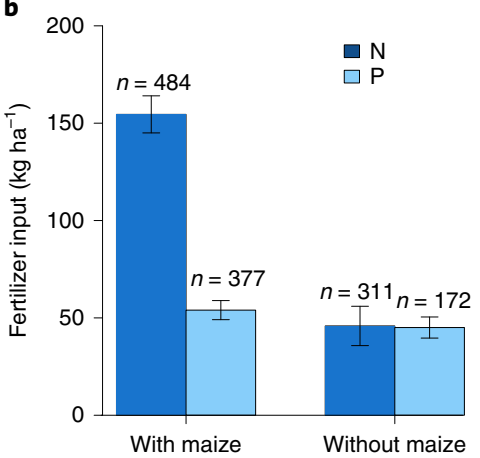

c

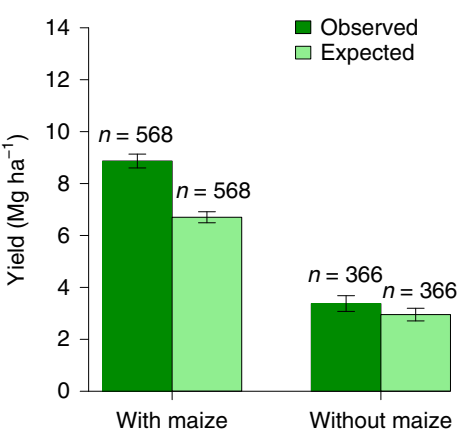

Fig. 3 | TND, fertilizer inputs and yield levels of intercrops with and without maize. a-c, TND (a), N and P fertilizer input (b), and observed yield and expected yield (c) of intercrops with and without maize.
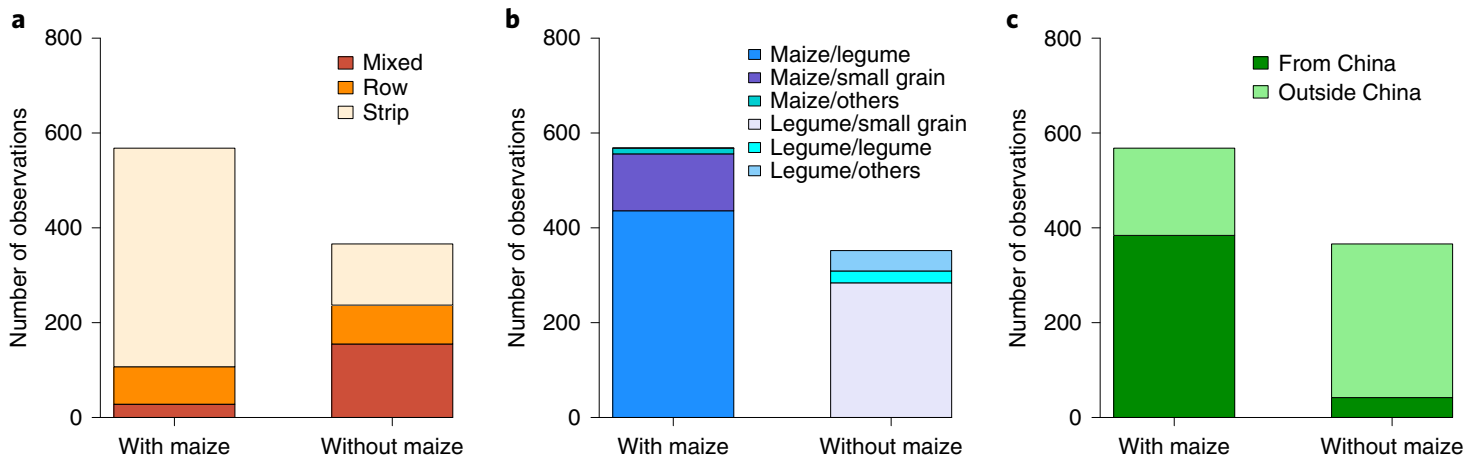

Fig. 4 | Spatial arrangements, species selection and geographic origin of intercrops with and without maize. a, Number of observations (records) for different intercropping patterns. b. Species selection (combinations with less than ten observations) are not shown. c, Studies on intercropping with or without maize originating from China and outside China.

Table 2). On the other hand, there are systems without maize with substantially lower yield levels, lower $\mathrm{N}$ input and often simultaneous alternate-row or mixed intercropping. Studies representing the high-yield intercropping syndrome with maize originated mostly from China, while studies representing the lower-yield intercropping syndrome without maize originated mostly outside China.

Relative metrics-LER, $\mathrm{N}$ fertilizer equivalent ratio (NFER) and $P$ fertilizer equivalent ratio (PFER) - were calculated to characterize the relative use efficiency of land (LER), $N$ fertilizer (NFER) and $P$ fertilizer (PFER) in intercropping. The LERs of intercrops with and without maize were both significantly larger than 1 , but the average LER of intercrops with maize $(1.29 \pm 0.02)$ was significantly greater than the average LER of intercrops without maize $(1.16 \pm 0.02)$ $(P<0.001$, Fig. 6a and Supplementary Fig. 5). Averaged over levels of $\mathrm{N}$ input, the land savings in intercrops with maize were $13 \%$ larger than in intercrops without maize. When $\mathrm{N}$ input was added as a categorical variable in this analysis, the effect of maize presence was still highly significant, but in addition there was a small but significant decrease in LER (by $0.05 \pm 0.02$ units, $P=0.004$ ) with higher $\mathrm{N}$ input. There was no significant interaction between $\mathrm{N}$ input and maize presence $(P=0.23)$ (Fig. 6a).

The NFER and PFER indicate the ratio of the fertilizer amounts used in sole cropping to the fertilizer amounts used under intercropping to produce equal amounts of yield. The NFERs of intercrops with and without maize were $1.33 \pm 0.04$ and $1.19 \pm 0.05$, respectively (Fig. 6b). So, to achieve the same yield as intercrops, the sole crops used $19-33 \%$ more $\mathrm{N}$ fertilizer than the intercrops, indicating increased $\mathrm{N}$ use efficiency in intercropping if nutrient use efficiency is expressed as fertilizer used per unit yield produced.
The NFER of intercrops with maize was higher $(P=0.01)$ than that of intercrops without maize, indicating that intercrops with maize save more $\mathrm{N}$ fertilizer compared with sole crops than do intercrops without maize. Similarly, the PFER of intercrops with maize $(1.36 \pm 0.03)$ was larger than the PFER of intercrops without maize $(1.19 \pm 0.04)(P<0.001$, Fig. 6b), indicating that, while both types of intercrops save $P$ fertilizer compared with sole crops, the savings are greater in intercrops with maize than in intercrops without maize.

\section{Discussion}

This paper presents a dichotomy in strategies for intercropping that could be regarded as two syndromes of production ${ }^{37,38}$. These different strategies have probably been developed to address different production objectives. On the one hand, systems with maize (commonly used in China) represent a strategy of intercropping based on high inputs, high outputs and a comparatively large intercropping advantage in terms of absolute yields per hectare. These systems are based on strip intercropping with narrow strips (usually $1-2 \mathrm{~m}$ wide) and a relay sequence in the sowing and harvesting of the intercropped species. Due to this relay sequence, the total duration of the intercropping system exceeds that of both component crops, providing the opportunity for increased capture of light, water and nutrient resources, and limiting the period of cogrowth, during which the species compete for resources. These relay systems obtain the greatest possible grain yield under land and resource constraints ${ }^{28,39,40}$.

On the other hand, systems without maize were often cultivated with low inputs, and they had substantially lower intercropping benefits in terms of absolute yield per hectare. These intercropping systems were usually grown as simultaneous intercrops, with 


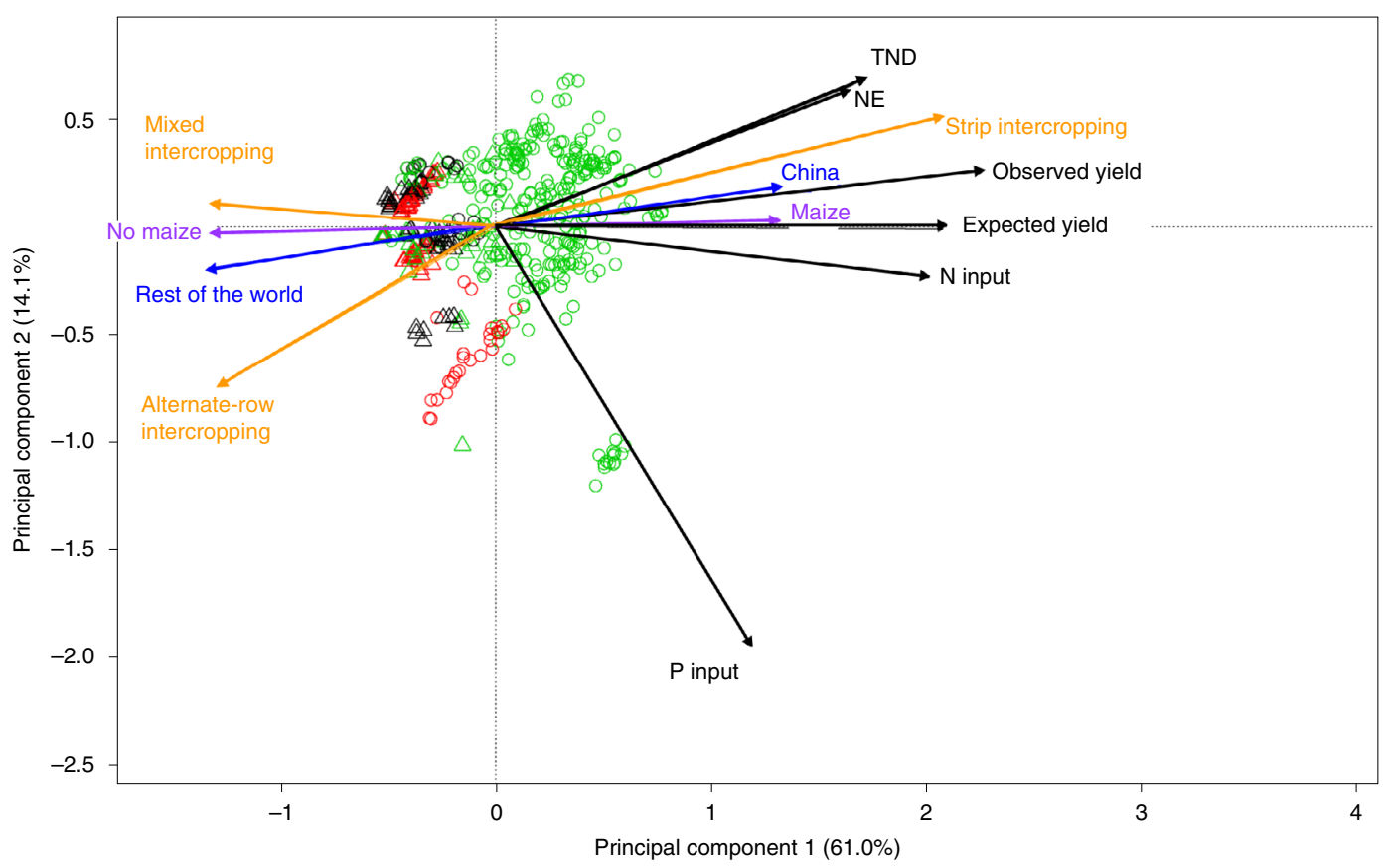

Fig. 5 | Principal component analysis of the associations between yield gain and intercropping design and management. The symbols represent mixed intercropping with maize (black circles) or without maize (black triangles), alternate-row intercropping with maize (red circles) or without maize (red triangles), and strip intercropping with maize (green circles) or without maize (green triangles). The arrows represent continuous variables (black) and categorical variables (coloured). The factor loadings are given in Supplementary Table 2.

simultaneous sowing and harvesting of the two species, and with the species grown most often in alternate rows or completely mixed, but rarely in strips. This type of system addresses the aim of developing an agricultural system that exploits species complementarities to drastically lower inputs, but these systems had lower outputs than the systems of the first syndrome. Due to the simultaneous sowing and harvesting, these systems are easier to mechanize than systems with maize, which are usually relay systems. Furthermore, due to the lower inputs, these systems are expected to have lower nutrient losses per hectare than systems managed according to the high-yield syndrome.

Land and fertilizer equivalent ratios were well above 1 (in the range of 1.16 to 1.36) in both syndromes of production, indicating that compared with sole crops, both strategies of intercropping resulted in considerable savings of land and nutrient resources. The relative efficiencies of intercrops compared with sole crops (LER, NFER and PFER) were greater in the case of the high-input, high-output syndrome than in the case of the low-input, low-output syndrome, leading to the unexpected finding that the benefits of diversifying agriculture are at least as high under high-input conditions as under low-input conditions.

Large intercropping benefits in production systems with high inputs contrast with the established opinion that the stress gradient hypothesis is a key explanation for intercropping benefits ${ }^{30}$. This hypothesis is based on the idea that under stressful conditions, facilitative and complementary species traits support the functioning of mixtures. While there is no doubt that this hypothesis explains many cases of overyielding in intercrops at low input levels, the current analysis shows that the benefits may be even greater if stresses are relieved, and intercropping is exploited to enhance resource capture and mitigate nutrient losses at higher input levels. The findings show that intercropping can be adapted to both low-input and high-input agriculture, on the basis of different production situations and socio-economic conditions with associated constraints and objectives, resulting in two syndromes characterized by a coordinated set of management practices.
In this analysis, we cannot disentangle the effect of maize from the effects of strip intercropping, relay intercropping or fertilizer inputs. Most of the maize intercrops were tall/short combinations, so intercrops were often sown in strips to reduce interspecific competition for light ${ }^{40,41}$ and to permit management by hand in smallholder farming. Maize is better adapted to high temperatures than $\mathrm{C} 3$ species, which makes a $\mathrm{C} 3 / \mathrm{C} 4$ mixture amenable to TND between component species. The spatial and temporal niche differentiation and the differences in plant height, photosynthesis mechanisms ${ }^{42}$, rooting patterns and phenology ${ }^{43}$ between maize and C3 species allow the complementary use of light, water and nutrient resources in intercropping. Legume-based intercrops were especially favoured in low-input (organic) agriculture to compensate for low external input and to make use of biological $\mathrm{N}_{2}$ fixation by legumes to maintain yield ${ }^{31,44}$.

The existence of these syndromes of production suggests different production orientations in different regions: high yield and high land use efficiency in China, and reduced inputs and low nutrient emissions outside China. In China, to achieve a stable food supply with limited land and resources, Chinese farmers developed and practised intercropping for thousands of years ${ }^{45}$. However, to maximize grain yields, fertilizer inputs have been strongly increased over the past few decades in most regions in China ${ }^{45,46}$, contrasting with traditional and circular patterns of low input and low output ${ }^{25}$. Tightened environmental policies may reduce inputs in China in the future ${ }^{47}$, both in intercropping and in sole crops, to diminish nutrient losses per hectare.

The high NFER and PFER of intercropping indicate that a 19\% (without maize) to $35 \%$ (with maize) reduction in fertilizer input may be achieved in intercropping as compared with sole crops while achieving the same amount of product output. The lower input of nutrients required per unit product in intercropping provides the potential to save fertilizer ${ }^{29}$ and reduce losses to the environment ${ }^{48,49}$ compared with monocultures that receive high inputs in China ${ }^{47}$. Nevertheless, despite the greater NFER and PFER (relative input per unit product), the high-input, high-output syndrome may still 

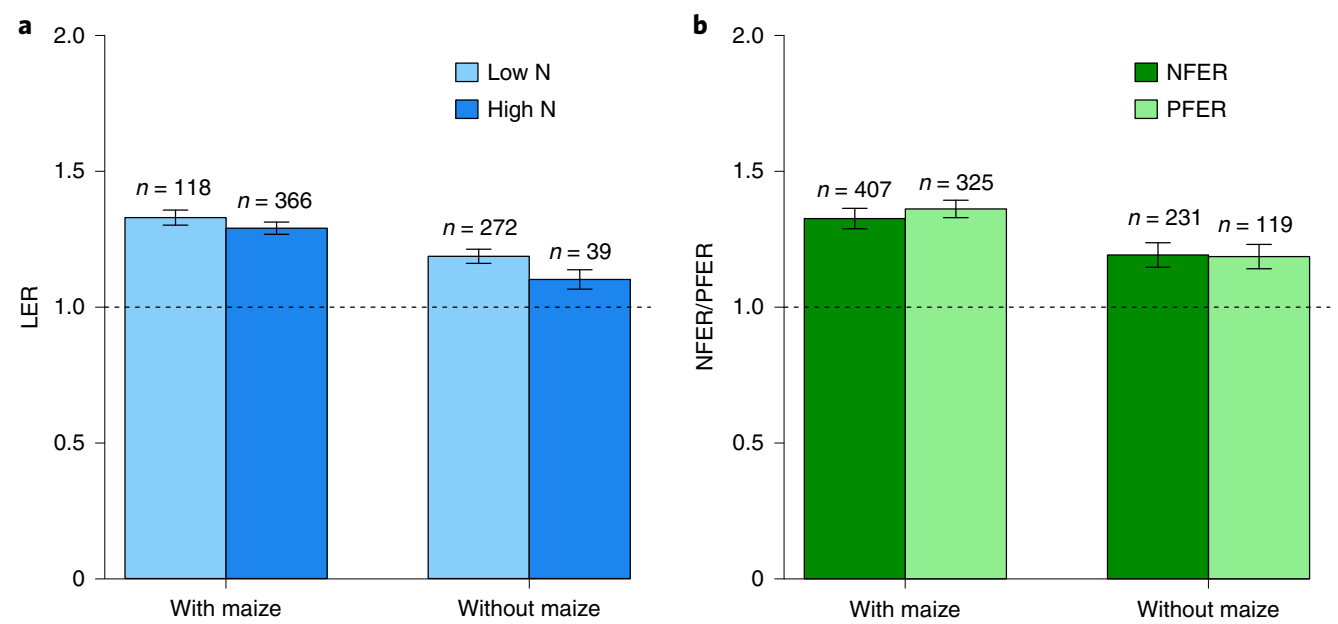

Fig. 6 | Land and fertilizer savings of intercropping. $\mathbf{a}$, Interaction between the effects of N input and maize presence on LER. $\mathbf{b}$, NFER and PFER of intercrops with and without maize. The dashed lines represent an LER, NFER or PFER equal to 1.

have higher nutrient emissions per hectare than the low-input, low-output syndrome. Further research is needed to assess the environmental benefits of the high-input intercropping strategy compared with sole crops or reduced-input intercrops. A middle way may be found between the low- and high-input strategies, combining the strengths of both, but this will require a further analysis of the trade-offs.

Intercropping is not currently a part of modern industrialized high-input and high-yield agriculture in Western nations. However, intercropping is gaining increasing interest in the context of sustainable agriculture in the West, and innovative farmers are experimenting with it, often using legumes to reduce $\mathrm{N}$ fertilizer inputs. Legume-based intercrops are used in organic farming to produce high-quality grain and forage at low $\mathrm{N}$ input ${ }^{21}$, to reduce $\mathrm{N}$ leaching $^{48}$ and to improve overall resilience by reducing pest and disease incidence $^{10}$, weed pressure ${ }^{9}$ and the risk of crop failure associated with drought or erratic rainfall ${ }^{50,51}$. Those intercrops are mostly fully mixed to adapt to sowing and harvesting with machinery in countries with high levels of mechanization ${ }^{21}$. Mixed intercropping is also practised by smallholder farmers in shifting cultivation systems with limited use of fertilizer and machinery $y^{6,50}$. Combining traits of both syndromes of production in intercropping may enable high food production with a lower environmental footprint than is realized in the currently existing high-input, high-output syndrome.

Our study suggests that intercropping strategies with maize provide an opportunity to design intercropping systems with large TND to adapt to extended growing seasons and higher temperatures due to global warming ${ }^{52,53}$. Furthermore, the temporal arrangement in relay strip intercropping allows better timing of fertilizer application to save fertilizer input. For instance, reduced $\mathrm{N}$ fertilizer input at the early cogrowth stage in maize/pea intercropping improves $\mathrm{N}_{2}$ fixation of intercropped pea, and $\mathrm{N}$ fertilization at the late cogrowth stage increases the recovery growth of intercropped maize ${ }^{54,55}$. The relatively high and stable crop productivity and economic benefits of intercropping are attractive to farmers ${ }^{56-58}$. However, the management of two crops in one field is more complex than that of a single crop, and markets may require high purity standards for harvested products that may be difficult to achieve if the crops are harvested simultaneously with existing machinery ${ }^{21,58}$. Strip relay intercropping may be a greater challenge for mechanization than simultaneous intercropping. Limited work on these challenges has been done, and work is currently ongoing to overcome these challenges ${ }^{46,59}$ and make mechanized intercropping possible ${ }^{60}$. The remarkable advantages of intercropping, and the possibility of applying intercropping under high-yield conditions, as shown here, should provide the incentive for stakeholders and policymakers to work on solving the current constraints and introduce much-needed diversity in agricultural systems ${ }^{2,61}$.

The current analysis did not consider water use in intercropping. In many production situations with high inputs and outputs, irrigation water is used. Relay intercropping increases the length of the growing season and thus increases total crop evaporation ${ }^{15}$. Therefore, intercrops need greater amounts of irrigation water than sole crops ${ }^{14}$. Nevertheless, previous work has shown that the increased water consumption in intercropping systems is more than offset by the higher productivity, such that the overall effect of intercropping is still an increase in water use efficiency (calculated per unit product) when compared with sole crops ${ }^{13,15,62}$. We did not include water use efficiency in the current analysis because our literature searches were not tailored to this variable. New systematic literature review and data retrieval are needed to analyse the worldwide water footprint of intercropping. On the basis of current knowledge, the likely outcome is that the high water use efficiency of intercropping can help alleviate water constraints in agriculture ${ }^{63}$. This is primarily due to species complementarities with respect to the location (soil depth) and timing (during the season) of water extraction ${ }^{13,14}$.

In conclusion, this meta-analysis presents two diverging syndromes of agricultural production by intercropping and suggests that these syndromes allow harvesting $16 \%$ to $29 \%$ more grain per hectare while using $19 \%$ to $36 \%$ less fertilizer per unit output than conventionally done in the monocrops of modern industrialized agriculture. Higher yields and lower inputs might mean greater profit to farmers $^{56-58}$, lowered environmental impacts ${ }^{48,56}$ and a more stable and secure food supply ${ }^{50,51}$. This meta-analysis shows how these advantages may be realized by intercropping in both high- and low-input agriculture. Intercropping therefore provides an important principle for advancing the sustainable intensification of agriculture.

\section{Methods}

Data selection. The dataset was built by combining a database built by Yu et al. ${ }^{23}$ and a database built by Li et al. ${ }^{35}$. From the original database of Yu et al. ${ }^{23}$, all the data records of grain-producing intercrops (such as cereals, legumes and oilseed crops) that provided data on species densities were extracted (539 records). We removed the duplicate data records ( 9 publications and 31 data records) in the two datasets. All intercrops in the resulting database were grain-producing intercrops. The dataset included variables such as the publication title, year and author, and the yield of both sole crops and intercrops, species combination, planting density, row distance, fertilizer input, sowing dates and harvest dates. Most of the studies did not report the irrigation frequencies and volumes in the 
different treatments. Therefore, irrigation amount was not included in the dataset. The dataset included 934 data records, representing data from 226 experiments described in 132 publications. 'Experiment' was defined as a unique combination of site and year. Within experiments, data records were defined by treatment, including species combination, sowing and harvest dates, and fertilizer input.

Response and explanatory variables. In the analysis, the response variables are NE, LER, NFER, PFER, rate of N (and P) fertilizer input in intercrops $\left(\mathrm{kg} \mathrm{ha}^{-1}\right)$, observed (and expected) yield $\left(\mathrm{Mgha}^{-1}\right)$, and TND (see equation (7) below), and the explanatory variables are the presence of maize in species combinations (categorical; two levels: with and without), the spatial arrangement (categorical; three levels: strip, row and mixed), the origin of the data (categorical; two levels: from China and outside China), TND, and the rate of $\mathrm{N}$ (and P) fertilizer input in the intercrops $\left(\mathrm{kgha}^{-1}\right)$

NE. The NE is defined as the difference between the observed yield and the expected yield ${ }^{24}$.

$$
\mathrm{NE}=\left(Y_{1}+Y_{2}\right)-\left(\mathrm{EY}_{1}+\mathrm{EY}_{2}\right)
$$

where $Y_{1}$ and $Y_{2}$ are the observed yields of species 1 and 2 in the intercrop, and $\mathrm{EY}_{1}$ and $\mathrm{EY}_{2}$ are the expected yields of the two species, which were calculated as the product of the monoculture yield and the land share ${ }^{35}$.

$$
\begin{aligned}
& \mathrm{EY}_{1}=M_{1} \times \mathrm{LS}_{1} \\
& \mathrm{EY}_{2}=M_{2} \times \mathrm{LS}_{2}
\end{aligned}
$$

where $M_{1}$ and $M_{2}$ are the yields (per unit area of the respective sole crop) of species 1 and 2 in monoculture, and $\mathrm{LS}_{1}$ and $\mathrm{LS}_{2}$ are the land shares of species 1 and 2 in intercropping. The land share was calculated on the basis of the densities of a species in the intercrop and in the sole crop or on the basis of the row or plant arrangement $t^{35}$.

LER. The LER is defined as the sum of partial LERs (relative yields) per species $\left(\mathrm{pLER}_{1}\right.$ and $\left.\mathrm{pLER}_{2}\right)$ :

$$
\mathrm{LER}=\mathrm{pLER}_{1}+\mathrm{pLER}_{2}=\frac{Y_{1}}{M_{1}}+\frac{Y_{2}}{M_{2}}
$$

where $Y_{1}$ and $Y_{2}$ are the yields (per unit of total area of the intercrop) of species 1 and 2 in intercropping, and $M_{1}$ and $M_{2}$ are the yields of species 1 and 2 in monoculture (same as above).

NFER and PFER. Because no $\mathrm{N}$ was applied to many of the legumes in some of the selected studies, we could not compare the $\mathrm{N}$ use efficiency of sole crops and intercrops. As an alternative, we used relative indicators. In analogy with the LER and water equivalent ratio ${ }^{13}$, we defined the NFER and PFER as the amount of $\mathrm{N}$ and $\mathrm{P}$ fertilizer used in sole crops to produce the same yields as obtained in intercropping.

$$
\begin{aligned}
& \text { NFER }=\frac{\text { Nfert }_{1} \times \frac{Y_{1}}{M_{1}}+\text { Nfert }_{2} \times \frac{Y_{2}}{M_{2}}}{\text { NferttC }} \\
& =\mathrm{pLER}_{1} \times \frac{\mathrm{Nfert}_{1}}{\text { Nfert }_{\mathrm{C}}}+\mathrm{pLER}_{2} \times \frac{\mathrm{Nfert}_{2}}{\text { Nfert }_{\mathrm{C}}} \\
& \text { PFER }=\frac{\text { Pfert }_{1} \times \frac{Y_{1}}{M_{1}}+\text { Pfert }_{2} \times \frac{Y_{2}}{M_{2}}}{\text { Pfert }_{\text {IC }}} \\
& =\mathrm{pLER}_{1} \times \frac{\text { Pfert }_{1}}{\text { Pfert }_{\text {IC }}}+\mathrm{pLER}_{2} \times \frac{\text { Pfert }_{2}}{\text { Pfert }_{C}}
\end{aligned}
$$

where $\mathrm{Nfert}_{\mathrm{IC}}$ and $\mathrm{Pfert}_{\mathrm{IC}}$ are the $\mathrm{N}$ and $\mathrm{P}$ fertilizer input per unit area $\left(\right.$ in $\left.\mathrm{kg} \mathrm{ha}^{-1}\right)$ of the intercrop ${ }^{35} ; \mathrm{Nfert}_{1}$ and Pfert ${ }_{1}$ are the $\mathrm{N}$ and $\mathrm{P}$ fertilizer input per unit area of species 1 in monoculture; and $\mathrm{Nfert}_{2}$ and $\mathrm{Pfert}_{2}$ are the $\mathrm{N}$ and $\mathrm{P}$ fertilizer input of species 2 in monoculture. The NFER and PFER express the relative amount of $\mathrm{N}$ and $\mathrm{P}$ fertilizer that would be required if sole crops were used to achieve the same yields as a unit area of intercrop. Values of the NFER and PFER larger than 1 indicate fertilizer savings in intercropping. An NFER and PFER equal to the LER indicate that the nutrient use efficiency gains of intercropping are primarily due to concentrating production on less land $\mathrm{d}^{29}$. If the fertilizer input in the intercrop is intermediate between those in the sole crops, the NFER and PFER will tend to be larger than the LER. If the fertilizer amount in the intercrop is higher than those in the sole crops, the NFER and PFER will tend to be smaller than the LER.

TND. An index for TND was used to express the proportion of the total growing period of an intercropping system in which species are growing alone. TND was calculated using the sowing and harvest dates of each species in the intercrop ${ }^{23}$ :

$$
\begin{aligned}
& \text { TND }=\frac{P_{\text {system }}-P_{\text {overlap }}}{P_{\text {system }}} \\
& =1-\frac{P_{\text {overlap }}}{P_{\text {system }}}
\end{aligned}
$$

where $P_{\text {overlap }}$ represents the period of overlap between the growing periods of the intercropped species, and $P_{\text {system }}$ represents the duration of the whole intercrop from the sowing of the first crop till the harvest of the last crop. A TND of 0 means full overlap of the two species (the species are sown and harvested at the same time). A TND of 1 means no overlap, which refers to double cropping (the second species is sown after the first is harvested). Double cropping was not included in our analysis.

Statistical analysis. Linear regression with mixed-effects models (function lme in R package nlme ${ }^{64,65}$ ) was used to estimate the average values of $\mathrm{NE}$, observed and expected yields, $\mathrm{N}$ and $\mathrm{P}$ fertilizer input, TND, LER, NFER, and PFER and to compare differences in these parameters between intercrops with and without maize, differences in NE between intercrops with different spatial arrangements, and the relationship between NE and TND or fertilizer input. We used the publication and the experiment within publications as random effects to account for differences among the studies (publications) and the experiments (sites $\times$ years) within studies. A variance model (function varIdent in R package nlme) was used to account for the heterogeneity of variance ${ }^{66}$ between intercrops with and without maize. The associations between the NEs of intercrops and the variables (such as $\mathrm{N}$ input, $\mathrm{P}$ input, TND, observed and expected yields, species combinations with and without maize, spatial arrangement and the origin of intercrops) were further visualized with principal component analysis, using the vegan package in $\mathrm{R}\left(\right.$ ref. $\left.{ }^{67}\right)$.

Reporting Summary. Further information on research design is available in the Nature Research Reporting Summary linked to this article.

\section{Data availability}

The datasets generated and analysed during the current study are available from the corresponding author on reasonable request.

\section{Code availability}

The $\mathrm{R}$ code used for the analysis is available from the corresponding author on reasonable request.

Received: 30 July 2019; Accepted: 28 April 2020;

Published online: 01 June 2020

\section{References}

1. Tilman, D., Balzer, C., Hill, J. \& Befort, B. L. Global food demand and the sustainable intensification of agriculture. Proc. Natl Acad. Sci. USA 108, 20260-20264 (2011)

2. Tilman, D., Cassman, K. G., Matson, P. A., Naylor, R. \& Polasky, S. Agricultural sustainability and intensive production practices. Nature 418, 671-677 (2002)

3. Matson, P. A., Parton, W. J., Power, A. G. \& Swift, M. J. Agricultural intensification and ecosystem properties. Science 277, 504-509 (1997).

4. Cassman, K. G. Ecological intensification of cereal production systems: yield potential, soil quality, and precision agriculture. Proc. Natl Acad. Sci. USA 96, 5952-5959 (1999).

5. Willey, R. W. Resource use in intercropping systems. Agric. Water Manage. 17, 215-231 (1990).

6. Vandermeer, J. H. The Ecology of Intercropping (Cambridge Univ. Press, 1989)

7. Ren, W. Z. et al. Can positive interactions between cultivated species help to sustain modern agriculture? Front. Ecol. Environ. 12, 507-514 (2014).

8. Martin-Guay, M. O., Paquette, A., Dupras, J. \& Rivest, D. The new green revolution: sustainable intensification of agriculture by intercropping. Sci. Total Environ. 615, 767-772 (2018).

9. Liebman, M. \& Dyck, E. Crop rotation and intercropping strategies for weed management. Ecol. Appl. 3, 92-122 (1993).

10. Trenbath, B. Intercropping for the management of pests and diseases. Field Crops Res. 34, 381-405 (1993).

11. Zhu, Y. et al. Genetic diversity and disease control in rice. Nature 406, $718-722(2000)$

12. Zhang, L. et al. Light interception and utilization in relay intercrops of wheat and cotton. Field Crops Res. 107, 29-42 (2008).

13. Mao, L. L. et al. Yield advantage and water saving in maize/pea intercrop. Field Crops Res. 138, 11-20 (2012).

14. Yang, C., Huang, G., Chai, Q. \& Luo, Z. Water use and yield of wheat/maize intercropping under alternate irrigation in the oasis field of northwest China. Field Crops Res. 124, 426-432 (2011).

15. Tan, M. et al. Dynamic process-based modelling of crop growth and competitive water extraction in relay strip intercropping: model development and application to wheat-maize intercropping. Field Crops Res. 246, 107613 (2020).

16. Hauggaard-Nielsen, H. et al. Pea-barley intercropping for efficient symbiotic $\mathrm{N}_{2}$-fixation, soil $\mathrm{N}$ acquisition and use of other nutrients in European organic cropping systems. Field Crops Res. 113, 64-71 (2009).

17. Jensen, E. S. Grain yield, symbiotic $\mathrm{N}_{2}$ fixation and interspecific competition for inorganic N in pea-barley intercrops. Plant Soil 182, 25-38 (1996).

18. Cong, W. F. et al. Intercropping enhances soil carbon and nitrogen. Glob. Change Biol. 21, 1715-1726 (2015). 
19. Li, L. et al. Diversity enhances agricultural productivity via rhizosphere phosphorus facilitation on phosphorus-deficient soils. Proc. Natl Acad. Sci. USA 104, 11192-11196 (2007).

20. Li, C. et al. Crop diversity for yield increase. PLoS ONE 4, e8049 (2009).

21. Bedoussac, L. et al. Ecological principles underlying the increase of productivity achieved by cereal-grain legume intercrops in organic farming: a review. Agron. Sustain. Dev. 35, 911-935 (2015).

22. Mead, R. \& Willey, R. The concept of a 'land equivalent ratio' and advantages in yields from intercropping. Exp. Agric. 16, 217-228 (1980).

23. Yu, Y., Stomph, T.-J., Makowski, D. \& van der Werf, W. Temporal niche differentiation increases the land equivalent ratio of annual intercrops: a meta-analysis. Field Crops Res. 184, 133-144 (2015).

24. Loreau, M. \& Hector, A. Partitioning selection and complementarity in biodiversity experiments. Nature 412, 72-76 (2001).

25. Li, L., Zhang, L. \& Zhang, F. in Encyclopedia of Biodiversity 2nd edn (ed. Levin, S.A.) 382-395 (Academic Press, 2013)

26. Lithourgidis, A., Dordas, C., Damalas, C. A. \& Vlachostergios, D. Annual intercrops: an alternative pathway for sustainable agriculture. Aust. J. Crop Sci. 5, 396-410 (2011)

27. Hong, Y. et al. Intercropping and agroforestry in China-current state and trends. Agric. Ecosyst. Environ. 244, 52-61 (2017).

28. Gou, F. et al. On yield gaps and yield gains in intercropping: opportunities for increasing grain production in northwest China. Agric. Syst. 151, 96-105 (2017)

29. $\mathrm{Xu}, \mathrm{Z}$. et al. Intercropping maize and soybean increases efficiency of land and fertilizer nitrogen use: a meta-analysis. Field Crops Res. 246, 107661 (2020)

30. Brooker, R. W. et al. Improving intercropping: a synthesis of research in agronomy, plant physiology and ecology. New Phytol. 206, 106-117 (2015).

31. Voisin, A. S. et al. Legumes for feed, food, biomaterials and bioenergy in Europe: a review. Agron. Sustain. Dev. 34, 361-380 (2014)

32. Barbieri, P., Pellerin, S. \& Nesme, T. Comparing crop rotations between organic and conventional farming. Sci. Rep. 7, 13761 (2017).

33. Lithourgidis, A. S., Vasilakoglou, I. B., Dhima, K. V., Dordas, C. A. \& Yiakoulaki, M. D. Forage yield and quality of common vetch mixtures with oat and triticale in two seeding ratios. Field Crops Res. 99, 106-113 (2006).

34. Bedoussac, L. et al. in Organic Farming, Prototype for Sustainable Agricultures (eds. Bellon, S. \& Penvern, S.) 47-63 (Springer, 2014)

35. Li, C. J. et al. Yield gain, complementarity and competitive dominance in intercropping in China: a meta-analysis of drivers of yield gain using additive partitioning. Eur. J. Agron. 113, 125987 (2020).

36. Hauggaard-Nielsen, H. \& Jensen, E. S. Evaluating pea and barley cultivars for complementarity in intercropping at different levels of soil $\mathrm{N}$ availability. Field Crops Res. 72, 185-196 (2001).

37. Andow, D. A. \& Hidaka, K. Experimental natural history of sustainable agriculture: syndromes of production. Agric. Ecosyst. Environ. 27, 447-462 (1989).

38. Vandermeer, J. Syndromes of production: an emergent property of simple agroecosystem dynamics. J. Environ. Manage. 51, 59-72 (1997).

39. Hong, Y., Heerink, N., Zhao, M. \& van der Werf, W. Intercropping contributes to a higher technical efficiency in smallholder farming: evidence from a case study in Gaotai County, China. Agric. Syst. 173, 317-324 (2019).

40. Li, L. et al. Wheat/maize or wheat/soybean strip intercropping I. Yield advantage and interspecific interactions on nutrients. Field Crops Res. 71, 123-137 (2001).

41. Liu, X. et al. Relationships among light distribution, radiation use efficiency and land equivalent ratio in maize-soybean strip intercropping. Field Crops Res. 224, 91-101 (2018).

42. Anten, N. \& Hirose, T. Shoot structure, leaf physiology, and daily carbon gain of plant species in a tallgrass meadow. Ecology 84, 955-968 (2003).

43. Anten, N. \& Hirose, T. Interspecific differences in above-ground growth patterns result in spatial and temporal partitioning of light among species in a tall-grass meadow. J. Ecol. 87, 583-597 (1999).

44. Fujita, K., Ofosubudu, K. G. \& Ogata, S. Biological nitrogen-fixation in mixed legume-cereal cropping systems. Plant Soil 141, 155-175 (1992).

45. Knörzer, H., Graeff-Hönninger, S., Guo, B., Wang, P. \& Claupein, W. in Climate Change, Intercropping, Pest Control and Beneficial Microorganisms (Ed. Lichtfouse, E.) 13-44 (Springer, 2009).

46. Du, J. B. et al. Maize-soybean strip intercropping: achieved a balance between high productivity and sustainability. J. Integr. Agric. 17, 747-754 (2018).

47. Ju, X. T. et al. Reducing environmental risk by improving $\mathrm{N}$ management in intensive Chinese agricultural systems. Proc. Natl Acad. Sci. USA 106, 3041-3046 (2009).

48. Whitmore, A. P. \& Schröder, J. J. Intercropping reduces nitrate leaching from under field crops without loss of yield: a modelling study. Eur. J. Agron. 27, 81-88 (2007).

49. Li, C. J. et al. Crop nitrogen use and soil mineral nitrogen accumulation under different crop combinations and patterns of strip intercropping in northwest China. Plant Soil 342, 221-231 (2011).
50. Rusinamhodzi, L., Corbeels, M., Nyamangara, J. \& Giller, K. E. Maize-grain legume intercropping is an attractive option for ecological intensification that reduces climatic risk for smallholder farmers in central Mozambique. Field Crops Res. 136, 12-22 (2012).

51. Raseduzzaman, M. \& Jensen, E. S. Does intercropping enhance yield stability in arable crop production? A meta-analysis. Eur. J. Agron. 91, 25-33 (2017).

52. Peñuelas, J. \& Filella, I. Responses to a warming world. Science 294, 793-795 (2001).

53. Menzel, A. \& Fabian, P. Growing season extended in Europe. Nature 397, 659 (1999).

54. Hu, F. L. et al. Improving $\mathrm{N}$ management through intercropping alleviates the inhibitory effect of mineral N on nodulation in pea. Plant Soil 412, 235-251 (2017)

$55 . \mathrm{Hu}, \mathrm{F}$. L. et al. Boosting system productivity through the improved coordination of interspecific competition in maize/pea strip intercropping. Field Crops Res. 198, 50-60 (2016).

56. Pelzer, E. et al. Pea-wheat intercrops in low-input conditions combine high economic performances and low environmental impacts. Eur. J. Agron. 40, 39-53 (2012).

57. Ngwira, A. R., Aune, J. B. \& Mkwinda, S. On-farm evaluation of yield and economic benefit of short term maize legume intercropping systems under conservation agriculture in Malawi. Field Crops Res. 132, 149-157 (2012).

58. Viguier, L., Bedoussac, L., Journet, E.-P. \& Justes, E. Yield gap analysis extended to marketable grain reveals the profitability of organic lentil-spring wheat intercrops. Agron. Sustain. Dev. 38, 39 (2018).

59. Iqbal, N. et al. Comparative analysis of maize-soybean strip intercropping systems: a review. Plant Prod. Sci. 22, 131-142 (2019).

60. Fletcher, A. L. et al. Prospects to utilise intercrops and crop variety mixtures in mechanised, rain-fed, temperate cropping systems. Crop Pasture Sci. 67, 1252-1267 (2017).

61. Wezel, A. et al. Agroecological practices for sustainable agriculture: a review. Agron. Sustain. Dev. 34, 1-20 (2014).

62. Chai, Q., Qin, A. Z., Gan, Y. T. \& Yu, A. Z. Higher yield and lower carbon emission by intercropping maize with rape, pea, and wheat in arid irrigation areas. Agron. Sustain. Dev. 34, 535-543 (2014).

63. Stomph, T. et al. in Advances in Agronomy (ed. Donald, L.S.) Vol. 160, 1-50 (Academic Press, 2020).

64. R Core Team. R: a language and environment for statistical computing ( Foundation for Statistical Computing, 2014); http://www.R-project.org/

65. Pinheiro, J. et al. nlme: linear and nonlinear mixed effects models. R package version 3.1-147 https://CRAN.R-project.org/package=nlme (2020).

66. Zuur, A., Ieno, E., Walker, N., Saveliev, A. \& Smith, G. Mixed Effects Models and Extensions in Ecology with $R$ (Springer Science \& Business Media, 2009).

67. Oksanen, J. et al. vegan: Community ecology package. $\mathrm{R}$ package version 2.4-3 https://cran.r-project.org, https://github.com/vegandevs/vegan (2017).

68. Gaudio, N. et al. Current knowledge and future research opportunities for modeling annual crop mixtures: a review. Agron. Sustain. Dev. 39, 20 (2019).

\section{Acknowledgements}

We acknowledge funding from the Chinese National Basic Research Program (grant no. 2015CB150400) and the National Key R\&D Program of China (grant no. 2017YFD0200200/2017YFD0200207). We also acknowledge the financial support of the Wageningen University Sandwich Scholarship. We acknowledge funding from the European Union's Horizon 2020 Programme for Research \& Innovation under grant agreement no. 727217 (www.remix-intercrops.eu). We also thank L. Bedoussac, L. Viguier, J. Du and W. Yang for providing the photographs included in Fig. 1.

\section{Author contributions}

C.L., E.H., T.W.K., C.Z., H.L., F.Z. and W.v.d.W. designed the study. C.L. and Y.Y. collected the data. C.L. and W.v.d.W. performed the statistical analyses and led the writing of the manuscript. All authors reviewed the manuscript and contributed to the interpretation and manuscript revisions.

\section{Competing interests}

The authors declare no competing interests.

\section{Additional information}

Supplementary information is available for this paper at https://doi.org/10.1038/ s41477-020-0680-9.

Correspondence and requests for materials should be addressed to F.Z. or W.v.d.W.

Peer review information Nature Plants thanks Frederick Stoddard, David Tilman and the other, anonymous, reviewer(s) for their contribution to the peer review of this work. Reprints and permissions information is available at www.nature.com/reprints. Publisher's note Springer Nature remains neutral with regard to jurisdictional claims in published maps and institutional affiliations.

(c) The Author(s), under exclusive licence to Springer Nature Limited 2020 


\section{Reporting Summary}

Nature Research wishes to improve the reproducibility of the work that we publish. This form provides structure for consistency and transparency in reporting. For further information on Nature Research policies, see Authors \& Referees and the Editorial Policy Checklist.

\section{Statistics}

For all statistical analyses, confirm that the following items are present in the figure legend, table legend, main text, or Methods section.

n/a $\mid$ Confirmed

$\square$ \. $\square$ The exact sample size $(n)$ for each experimental group/condition, given as a discrete number and unit of measurement

$\square$ \ A statement on whether measurements were taken from distinct samples or whether the same sample was measured repeatedly

The statistical test(s) used AND whether they are one- or two-sided

$\bigotimes$ Only common tests should be described solely by name; describe more complex techniques in the Methods section.

$\square$ \ A description of all covariates tested

$\square$ \ A description of any assumptions or corrections, such as tests of normality and adjustment for multiple comparisons

$\square$ A full description of the statistical parameters including central tendency (e.g. means) or other basic estimates (e.g. regression coefficient)

$\triangle$ AND variation (e.g. standard deviation) or associated estimates of uncertainty (e.g. confidence intervals)

$\square$ For null hypothesis testing, the test statistic (e.g. $F, t, r$ ) with confidence intervals, effect sizes, degrees of freedom and $P$ value noted

$\square$ Give P values as exact values whenever suitable.

Х $\square$ For Bayesian analysis, information on the choice of priors and Markov chain Monte Carlo settings

$\square$ \. For hierarchical and complex designs, identification of the appropriate level for tests and full reporting of outcomes

$\square$ ¿stimates of effect sizes (e.g. Cohen's $d$, Pearson's $r$ ), indicating how they were calculated

Our web collection on statistics for biologists contains articles on many of the points above.

\section{Software and code}

Policy information about availability of computer code

Data collection Data was collected from the Chinese knowledge infrastructure and Web of Science. The search and selection process is presented in detail.

Data analysis

R version 3.3.3 was used for data analysis.

For manuscripts utilizing custom algorithms or software that are central to the research but not yet described in published literature, software must be made available to editors/reviewers. We strongly encourage code deposition in a community repository (e.g. GitHub). See the Nature Research guidelines for submitting code \& software for further information.

\section{Data}

Policy information about availability of data

All manuscripts must include a data availability statement. This statement should provide the following information, where applicable:

- Accession codes, unique identifiers, or web links for publicly available datasets

- A list of figures that have associated raw data

- A description of any restrictions on data availability

The datasets generated during and/or analysed during the current study are available from the corresponding author on reasonable request.

\section{Field-specific reporting}

Please select the one below that is the best fit for your research. If you are not sure, read the appropriate sections before making your selection. 


\section{Ecological, evolutionary \& environmental sciences study design}

All studies must disclose on these points even when the disclosure is negative.

Study description

We did a global meta-analysis on comparing the difference in absolute yield gain of different intercropping strategies and we analysed how a coherent of management factors such as species choice, intercropping patterns, temporal niche differentiation and fertilizer input impact the yield gain of intercropping. We found that there are two syndromes of production in intercropping: highinput and hight-yield system and low-input and low-yield system. And we discussed the reasons for the syndromes in the context of ecology, socio-economic forces, and we discussed the implication of our study for future intercropping design and challenges of mechanisation in intercropping.

Research sample

The dataset was built by collecting literature data from Web of Science and from the Chinese National Knowledge Infrastructure. The dataset includes sufficient information for our analysis, such as the yields of sole crops and intercrops in each study, the sowing dates and harvesting dates of each crop, the species combinations in intercropping, the intercropping patterns and the nutrient input rates, etc (Li et al. (2020) and Yu et al. (2015)).

Yu, Y., Stomph, T.-J., Makowski, D., Van der Werf, W., 2015. Temporal niche differentiation increases the land equivalent ratio of annual intercrops: A meta-analysis. Field Crops Research 184, 133-144.

Li, C. J. et al. 2020. Yield gain, complementarity and competitive dominance in intercropping in China: A meta-analysis of drivers of yield gain using additive partitioning. European Journal of Agronomy 113:125987 doi:https://doi.org/10.1016/j.eja.2019.125987

Sampling strategy

The search and selection strategy for the dataset about Chinese intercropping is fully described in Li et al. (2020). Another dataset is a subset of Yu et al. (2015), and the search and selection process is clearly included in the paper and our selection of the subset is included in the manuscript.

Data collection

One data set (about Chinese intercropping) was built by collecting data in literature from the Chinese National Knowledge Infrastructure. Chunjie Li collected the data, and the data collection criteria are included in Li et al. (2020). The other data set (about non-Chinese intercropping) was a subset of a database compiled by Yu et al. (2015). The selection procedure is included in the paper and supplementary information. Yang Yu collected the original data set, and Chunjie Li did the selection of subset. The selection criteria are included in Materials and Methods of the manuscript.

Timing and spatial scale

We built the data set about Chinese intercropping in January 2015. The subset of Yu et al. (2015) about non-Chinese intercropping was built in 2012.

Data exclusions

No data was excluded from the analysis.

Reproducibility

The study is fully reproducible using the data and methods detailed in the manuscript.

Randomization

The dataset about Chinese intercropping is a sample by searching literature before January 2015 from the available online literature sources (Web of Science and Chinese National Knowledge Infrastructure). The other dataset about non-Chinese intercropping is a sample from literature, and the sampling strategy is described in Yu et al. (2015).

Blinding

Blinding is not relevant to our study.

Did the study involve field work? $\square$ Yes $\$ No

\section{Reporting for specific materials, systems and methods}

We require information from authors about some types of materials, experimental systems and methods used in many studies. Here, indicate whether each material, system or method listed is relevant to your study. If you are not sure if a list item applies to your research, read the appropriate section before selecting a response.

\begin{tabular}{|c|c|}
\hline n/a & Involved in the study \\
\hline$\bigotimes$ & $\square$ Antibodies \\
\hline Х & Eukaryotic cell lines \\
\hline Х & Palaeontology \\
\hline$\bigotimes$ & $\square$ Animals and other organisms \\
\hline$\bigotimes$ & $\square$ Human research participants \\
\hline$\bigotimes$ & $\square$ Clinical data \\
\hline
\end{tabular}

n/a Involved in the study

$\bigotimes \square$ ChIP-seq

Х $\square$ Flow cytometry

$\bigotimes \square$ MRI-based neuroimaging 